\title{
PEMBUATAN KOMPOS DARI LIMBAH PERTANIAN SEBAGAI SOLUSI PENGADAAN PUPUK SECARA MANDIRI OLEH MASYARAKAT DI DESA WAY TUBA DAN CAMPUR ASRI KABUPATEN WAY KANAN
}

\author{
Buhani $^{1 *}$, Suharso² dan Riko Noviadi ${ }^{3}$ \\ 1,2,3 Jurusan Kimia FMIPA, Universitas Lampung \\ *email: buhani@fmipa.unila.ac.id
}

\begin{abstract}
Waste management based on community participation that aims to implement the 4Rp concept (Reduce, Reuse, Recycle, Replace, Participation) has been implemented through the Regional Partnership Program (PKW) of Ministry of Research, Technology and Higher Education, by the PKW Team from the University of Lampung, in collaboration with Polinela and Government of Way Kanan District through the Environmental Services. This program was performed to manage the agricultural waste independently by the communities to reduce the amount of midden that must be managed at the landfill and it can provide an economic added value. These activities have been carried out in two villages, namely Way Tuba Village - Sub-district of Gunung Labuhan and Campur Asri Village, Sub-district of Baradatu, which have potency of the agricultural waste in Way Kanan District. In general, the results of these activities have increased community participation and knowledge of the paradigm of waste and waste management with the concept of the $4 \mathrm{Rp}$, procurement of fertilizers/compost independently, as well as being a pioneer of waste management based on active participation from the community. In addition, this program has provided solutions to the community to produce fertilizers/compost independently, either to be used for their own needs or sold to meet fertilizer/compost needs in the surrounding environment.
\end{abstract}

Keywords: Waste management, 4RP method, compost.

\section{PENDAHULUAN}

Kabupaten Way Kanan merupakan salah satu wilayah di Propinsi Lampung yang didominasi oleh usaha di bidang perkebunan dan pertanian. Hal ini dapat diamati melalui pemanfaatan lahan untuk sumber mata pencaharian masyarakat di bidang perkebunan dan pertanian sebesar $35,2 \%$ sedangkan sisanya lahan tersebut digunakan sebagai hutan produksi sebesar 17,10 , hutan lindung 5,68 , sawah 3,70 , perladangan 3,72 , pekarangan 3,72 , kolam, tambak dan rawa 0,47 , dan tegalan 18,1 serta lahan yang tidak diusahakan $12,50 \%$. Dari data tersebut menunjukkan bahwa sebagian besar masyarakat di Kabupaten Way Kanan sangat bergantung pada bidang perkebunan dan pertanian (WKDA, 2015). Hasil perkebunanan dan pertanian tersebut meliputi: karet, kelapa sawit, kelapa, kopi, lada, kakao, singkong, dan cengkeh serta tanaman pangan lainnya. 


\section{Website : http://jurnal.untan.ac.id/index.php/JPLP2KM ISSN : $2620-4665$ (print) \\ ISSN : $2620-4673$ (online)}

Untuk mewujudkan program peningkatan produktivitas perkebunan dan pertanian, maka pemkab Way Kanan berupaya melibatkan masyarakat sebagai mitra. Salah satu upaya tersebut dilakukan melalui pemanfaatan sampah rumah tangga, limbah perkebunan dan pertanian yang diolah sebagai kompos untuk menciptakan kemandirian masyarakat terhadap kebutuhan pupuk organik dan mengurangi ketergantungan terhadap pupuk sintetik dalam rangka meningkatkan produktivitas perkebunan dan pertanian.

Potensi limbah perkebunan dan pertanian untuk diolah menjadi kompos di pemkab Way Kanan sangat besar, karena sebagian besar masyarakatnya bermata pencaharian di bidang pertanian dan perkebunan (BPS Way Kanan, 2014). Sebagian besar limbah perkebunan seperti kulit buah kakao, kulit buah kopi, kulit singkong, pelepah dan tandan kosong kelapa sawit, limbah tebu, pelepah dan limbah sabut kelapa merupakan biomassa yang sangat berpotensi untuk diproses menjadi pupuk organik yang bermanfaat untuk meningkatkan kesuburan tanah dan memperbaiki struktur tanah secara alami (Buhani dkk., 2018; Suharso and Buhani, 2011). Selain itu juga program tersebut bertujuan meningkatkan kesadaran masyarakat akan pentingnya menjaga kelestarian lingkungan (Buhani dkk, 2017; Radar Lampun, 2017).

Sampah yang tidak dikelola dengan baik sering terlihat dibiarkan bertumpuk di tempattempat terbuka, dibuang ke sungai, ke selokan, atau dibakar. Banyak masyarakat juga yang masih berperilaku membuang sampah sembarangan baik di jalanan mau pun di lingkungan tempat tinggalnya. Sampah yang tidak dikelola menyebabkan dampak negatif baik langsung mau pun tidak langsung bahkan dapat mengakibatkan pencemaran lingkungan oleh bahan kimia toksik baik berupa senyawa organik maupun anorganik seperti logam berat (Buhani dkk., 2017; Buhani dkk., 2015; Buhani dkk.,2012; Suharso dan Buhani, 2011; Buhani dkk., 2011). Dampak negatif langsung diantaranya lingkungan menjadi kumuh, kotor, menimbulkan bau tak sedap dan berpotensi menjadi sumber penyakit yang akan berdampak bagi kesehatan warga.

Program pengelolaan dan pengolahan sampah sudah dirintis di Pemerintah Kabupaten (Pemkab) Way Kanan, yaitu melalui program Bank Sampah (Antara Lampung, 2016; Tribun Lampung, 2016)),akan tetapi karena program ini baru diluncurkan, maka partisipasi masyarakat masih rendah. Sehingga diperlukan upaya sosialisasi dan peningkatan kesadaran dan pemahaman masyarakat akan pentingnya pengelolaan sampah bagi kesehatan dan lingkungan hidup serta pemanfaatannya untuk menambah penghasilan. Upaya yang telah dilakukan adalah meningkatkan partisipasi masyarakat dalam pengelolaan sampah dengan melakukan reduksi 


\section{Website : http://jurnal.untan.ac.id/index.php/JPLP2KM ISSN : $2620-4665$ (print) \\ ISSN : $2620-4673$ (online)}

sampah di sumbernya (rumah tangga) serta limbah perkebunan dan pertanian. Dalam rangka mengimplementasikan kegiatan tersebut, Universitas Lampung, Pemkab Way Kanan, dan perguruan tinggi mitra yaitu Politeknik Negeri Lampung membentuk pilot project pengelolaan sampah berbasis masyarakat melalui PKW dari Kemenristekdikti. Pengelolaan sampah berbasis masyarakat bertujuan untuk menerapkan konsep 4Rp melalui PKW dari Kemeristekdikti, sehingga sampah/limbah pertanian dapat dikelola secara mandiri oleh masyarakat di tingkat sumber, dan dapat mengurangi jumlah timbulan sampah yang harus dikelola di TPS atau TPA, serta dapat memberikan nilai tambah secara ekonomi. Kegiatan ini telah dilaksanakan di desa Way Tuba dan desa Campur Asri yang memiliki potensi sampah/limbah perkebunan dan pertanian di Kabupaten Way Kanan. Secara umum, hasil kegiatan tersebut telah meningkatkan partisipasi dan pengetahuan masyarakat terhadap paradigma tentang sampah dan pengelolaan sampah dengan konsep 4Rp, pengadaan pupuk/kompos secara mandiri, serta menjadi pelopor pengelolaan sampah berbasis partisipasi aktif dari masyarakat.

\section{METODE}

Kegiatan PKW ini dilakukan melalui beberapa tahapan meliputi: sosialisasi kegiatan, pembentukan kelembagaan, dan tahap pengelolaan dan pengolahan sampah menjadi kompos yan berasal dari bahan utama limbah pertanian yang berupa kulit kopi dan serbuk gergaji kayu serta bahan organik lainnya dari daun-daunan.

\subsection{TAHAP SOSIALISASI KEGIATAN}

Pada tahap ini ide pengelolaan sampah mandiri disosialisasikan terlebih dulu kepada pengurus RT/RW, tokoh masyarakat, tokoh agama, dan organisasi kemasyarakatan lainnya sebelum dilanjutkan ke masyarakat. Kemudian dilanjutkan dengan kegiatan yang berkaitan dengan teknis penggunaan peralatan serta perlengkapan yang ada, seperti tempat penampungan sampah organik, kantong untuk sampah plastik, kertas dan kaca (PKKc), serta tempat sampah campursari. Kegiatan sosialisasi dilanjutkan dengan pembentukan organisasi informal oleh dan untuk masyarakat yang akan menjadi pilot project. Fungsi dari organisasi ini adalah menjalankan pengelolaan sampah. Organisasi ini memiliki sejumlah kader yang bertugas memberikan penyuluhan, pendampingan, maupun pengawasan dalam menerapkan konsep pengelolaan sampah berbasis masyarakat. 
Website : http://jurnal.untan.ac.id/index.php/JPLP2KM ISSN : $2620-4665$ (print)

ISSN : $2620-4673$ (online)

\subsection{TAHAP PELAKSANAAN PENGELOLAAN SAMPAH}

Kegiatan ini dimulai dari: (a) pemilahan sampah yang merupakan kegiatan berupa aktivitas memisahkan dan mengelompokkan sampah sesuai dengan jenis sampah. Kegiatan ini dilakukan masing-masing warga. Pemilahan sampah disesuaikan dengan kelompok sampah yang sudah disepakati pada saat sosialisasi kegiatan; (b) teknik pengomposan: sampah organik dimasukkan ke dalam tong komposter yang telah diberikan atau dibuat dan dibagikan ke masyarakat. Sampah organik yang berukuran besar dicacah terlebih dulu baru kemudian dimasukkan ke komposter. Komposter kemudian ditutup. Untuk mempercepat pengomposan, setiap hari dapat diberikan MOL (mikroorganisme lokal) yang dibuat sendiri, atau starter lain yang sudah jadi. Penambahan agen starter ini membuat teknik pengomposan menjadi lebih cepat, tidak berbau, dan mudah. Penambahan sampah organik dapat dilakukan sampai komposter penuh. Kompos yang dihasilkan dapat digunakan secara langsung pada tanaman masyarakat atau juga bisa dijual kepada masyarakat lain yang membutuhkan.

\subsection{MONITORING DAN EVALUASI}

Kegiatan pemantauan dan evaluasi merupakan kegiatan yang sangat penting dalam sebuah program kegiatan. Pemantauan dan evaluasi dilakukan dalam rangka mengetahui sejauh mana program telah dilaksanakan sesuai dengan rencana. Agar arah program tetap berjalan sesuai dengan tujuan program. Evaluasi juga dilakukan untuk mengetahui tingkat minat atau perhatian peserta pada pelaksanaan kegiatan.

Evaluasi kegiatan dilakukan dengan tujuan untuk mengetahui tingkat minat atau perhatian peserta pada pelaksanaan kegiatan. Evaluasi kegiatan dilakukan dengan mengadakan pre-test dan post-test untuk membandingkan beberapa parameter ukur yang meliputi tentang peningkatan minat, pengetahuan, kemampuan, kesadaran, dan keterampilan peserta untuk mengolah sampah berdasarkan konsep 4Rp. Sebelum kegiatan penyuluhan dan praktik dilakukan serangkaian pretest untuk mengetahui pemahaman peserta terhadap beberapa pertanyaan yang diajukan berkaitan dengan pengelolaan dan pengolahan sampah. Beberapa pertanyaan pre-test sekaligus menjadi pertanyaan pos-test dalam rangka membandingkan hasil kegiatan penyuluhan disusun sesuai dengan Tujuan Intruksional Khusus (TIK) yang ingin dicapai dalam kegiatan ini seperti : (1) pengetahuan peserta terhadap pengelolaan dan pengolahan sampah rumah tangga, pertanian/perkebunan; (2) pengetahuan peserta dalam pembuatan kompos skala rumah tangga; 
Website : http://jurnal.untan.ac.id/index.php/JPLP2KM ISSN : $2620-4665$ (print)

ISSN : 2620 - 4673 (online)

(3) pengetahuan peserta dalam mengolah limbah pertanian menjadi kompos dalam skala besar; (4) pengetahuan menggunakan kompos sebagai pupuk secara tepat.

\section{HASIL DAN PEMBAHASAN}

Pada kegiatan PKW di desa Desa Way-Tuba Kecamatan Gunung Labuhan dan Campur Asri Kecamatan Baradatu Kabupaten Way Kanan telah dilakukan peningkatan partisipasi masyarakat dalam pengolahan dan pengelolaan sampah, terbentuknya sistem pengelolaan sampah berbasis komunitas pertanian dengan menerapkan teknologi pengomposan sehingga terbentuk lingkungan yang bersih dan sehat melalui kegiatan peningkatan skala, spesifikasi produk kompos, penggunaan ke tanaman, dan teknik pengemasan kompos.

Peningkatan partisipasi masyarakat dilakukan melalui beberapa tahapan, antara lain: sosialisasi merupakan langkah awal bagi penyampaian wacana baru dalam melihat dan memahami sekaligus merupakan upaya pendekatan kepada masyarakat untuk menerapkan pengelolaan sampah dalam sudut pandang yang berbeda, adaptif terhadap permasalahan pengelolaan sampah kontemporer, dan tentunya bersifat ramah terhadap lingkungan.

Pada pelaksanaan kegiatan PKW ini dilakukan beberapa tahapan sosialisasi, yaitu dimulai sosialisasi ide pengelolaan sampah mandiri kepada pengurus RT/RW, tokoh masyarakat, tokoh agama, dan organisasi kemasyarakatan lainnya sebelum dilanjutkan ke masyarakat. Kemudian, kegiatan sosialisasi dilanjutkan kepada masyarakat yang berminat dalam pengelolaan sampah.

Proses sosialisasi implementasi kegiatan pemilahan sampah ini merupakan sebuah kegiatan untuk merealisasikan konsep 4Rp di lapangan. Proses ini mulai berjalan di tengah masyarakat terutama setelah berbagai peralatan dan perlengkapan tersedia dan telah dibagikan kepada masyarakat yang sudah terdaftar. Sosialisasi yang dilakukan pada tahap ini berkaitan dengan teknis penggunaan peralatan serta perlengkapan yang ada, seperti tempat penampungan sampah organik, kantong untuk sampah plastik, kertas dan kaca (PKKc), serta tempat sampah campursari.

Kegiatan PKW di Desa Way Tuba dan Desa Campur Asri telah mengubah pradigma masyarakat akan pentingnya pemanfaatan sampah menjadi kompos yang sangat bermanfaat dalam memenuhi kebutuhan pupuk secara mandiri, seperti yang diperoleh dari hasil analisis kuesioner yang diberikan kepada masyarakat yang ditampilkan pada Tabel 1. 
Tabel 1. Hasil analisis TIK sebelum dan setelah dilakukan kegiatan PKW pengolahan sampah menjadi kompos.

\begin{tabular}{lccc}
\hline \multicolumn{1}{c}{ TIK } & \multicolumn{3}{c}{ Persentase (\%) } \\
& Pre-test & Post-test & Peningkatan \\
\hline 1 (soal 1 dan 2) & 43,0 & 90,0 & 47,0 \\
2 (soal 3 dan 4) & 35,0 & 87,0 & 52,0 \\
3 (soal 5 dan 6) & 35,0 & 82.0 & 47,0 \\
4 (soal 7 dan 8) & 33,0 & 84,0 & 51,0 \\
\hline Rerata & $\mathbf{3 6 , 5}$ & $\mathbf{7 8 , 0}$ & $\mathbf{4 9 , 3}$ \\
\hline
\end{tabular}

Dari hasil analisis analisis TIK sebelum dan setelah dilakukan kegiatan PKW yang tertera pada Tabel 1, dapat diamati bahwa secara umum, kegiatan ini telah meningkatkan partisipasi dan pengetahuan masyarakat terhadap paradigma tentang sampah dan pengelolaan sampah dengan konsep 4Rp, pengadaan pupuk/kompos secara mandiri dengan persentase rata-rata peningkatan dari 36,5 menjadi $78 \%$ atau terjadi peningkatan sebesar $49,3 \%$. Hal ini menunjukkan bahwa masyarakat telah berpartisipasi dengan baik dan mengindikasikan bahwa kegiatan ini telah berhasil meningkatkan pengetahuan mitra dalam memahami dan menyadari serta telah menerapkan pengelolaan dan pengolahan sampah menjadi bahan yang bermanfaat seperti kompos.

Hasil analisis partisipasi masyarakat seperti yang tertera pada Tabel 1 didukung oleh produk pengolahan sampah pada kedua desa, baik di Desa Way Tuba maupun di Desa Campur Asri, seperti yang ditampilkan pada Gambar 2.
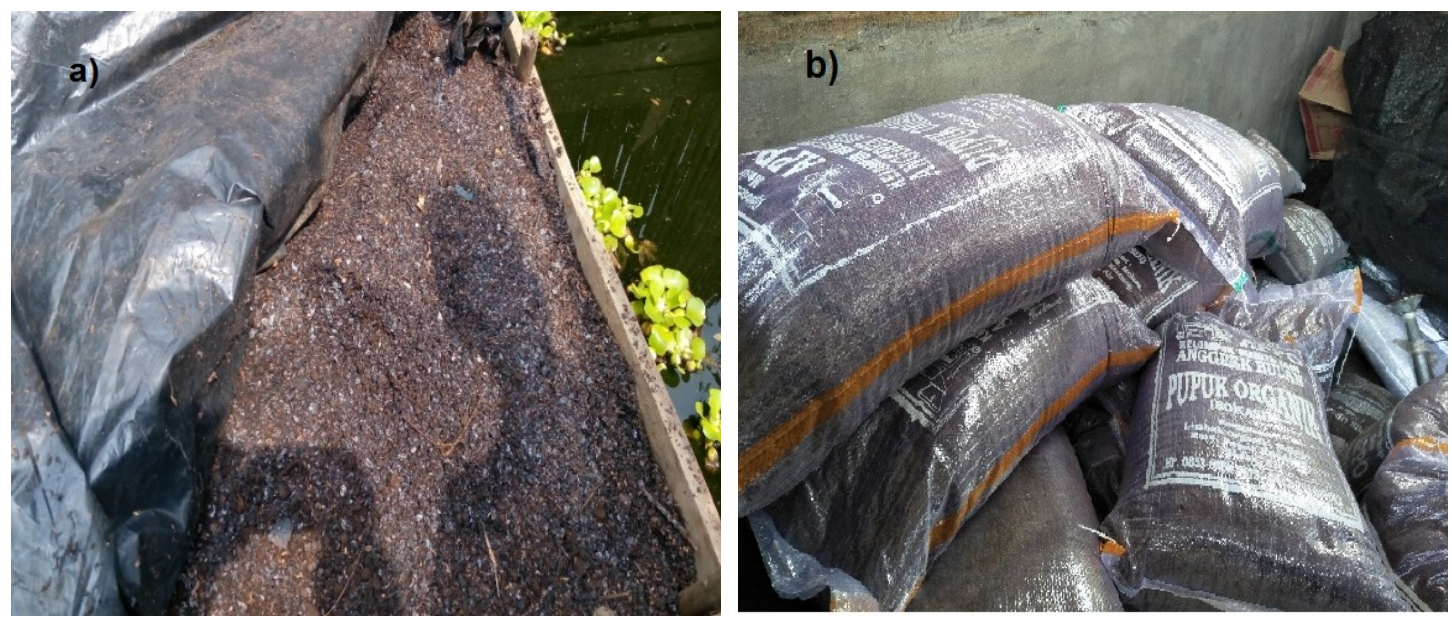


\section{Website : http://jurnal.untan.ac.id/index.php/JPLP2KM ISSN : $2620-4665$ (print) ISSN : $2620-4673$ (online)}

Gambar 1. Produk kompos hasil olahan limbah pertanian/perkebunan a) Desa Way-Tuba dan b) Desa Campur Asri

Hasil pengolahan sampah pertanian/perkebunan (Gambar 1) juga telah diterapkan sebagai pupuk pada tanaman masyarakat seperti yang disajikan pada Gambar 2.
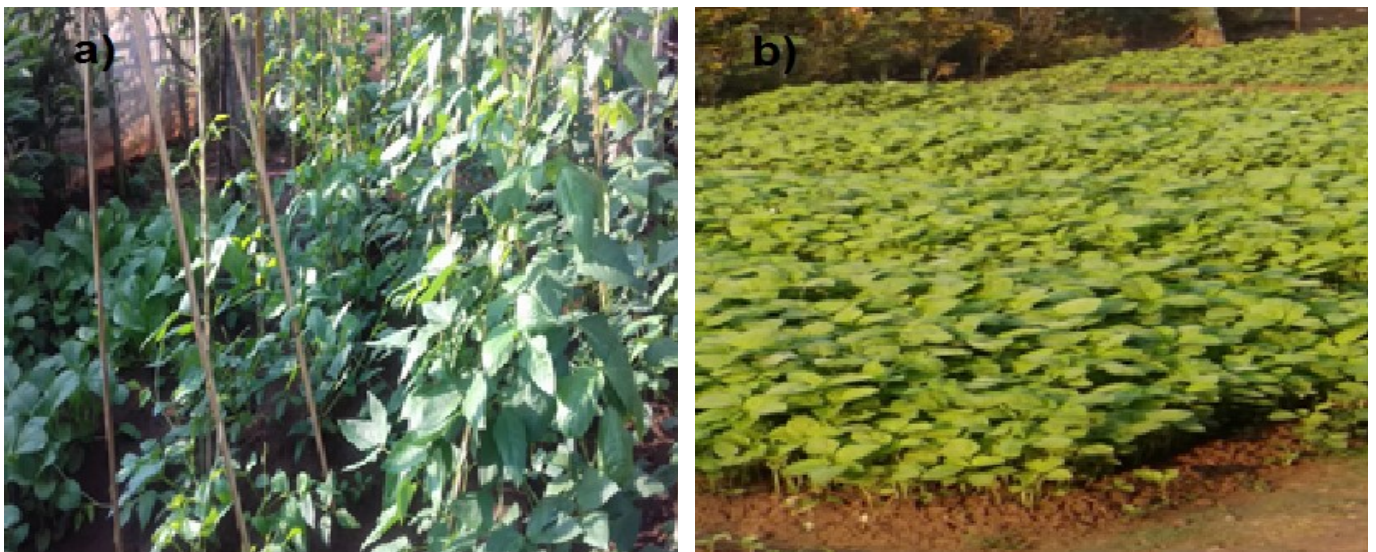

Gambar 2. Penerapan kompos hasil olahan limbah pertanian/perkebunan pada tanaman a) Kacang panjang di Desa Way-Tuba dan b) Bayam di Desa Campur Asri

Komposisi unsur kompos dari limbah pertanian yang berupa kulit kopi dan bahan sisa gergaji kayu serta bahan organik dari daun-daunan dari kegiatan PKW di desa Way Tuba dan Campur Asri juga telah dianalisis untuk mengetahui kualitas kompos dibandikan dengan SNI kompos yang dihasilkan seperti yang tertera pada Tabel 2.

Tabel 2. Komposisi unsur kompos dari olahan sampah pertanian/perkebunan desa Way Tuba dan Campur Asri

\begin{tabular}{lccc}
\hline \multirow{2}{*}{ Parameter } & \multicolumn{3}{c}{ Persentase Unsur dalam Kompos } \\
\cline { 2 - 4 } & Desa Way-Tuba & Desa Campur Asri & SNI Kompos \\
\hline Nitrogen & 1,92 & 2,80 & 0,40 \\
P-total & 1,10 & 2,03 & 0,10 \\
Kalium $\left(\mathrm{K}_{2} \mathrm{O}\right)$ & 2,90 & 1,78 & 0,20 \\
Kalsium $(\mathrm{Ca})$ & 4,20 & 0,76 & 25,50 \\
Magnesium $(\mathrm{Mg})$ & 0,22 & 0,32 & 0,60 \\
C-Organik & 12,51 & 15,40 & 9,80 \\
C/N rasio & 6,51 & 5,50 & 10,0 \\
\hline
\end{tabular}




\section{Website : http://jurnal.untan.ac.id/index.php/JPLP2KM ISSN : $2620-4665$ (print) \\ ISSN : $2620-4673$ (online)}

Dari Tabel 2 dapat diamati bahwa nilai $\mathrm{C} / \mathrm{N}$ rasio kompos dari kedua desa tersebut masih belum memenuhi standar SNI kompos. Dengan demikian diperlukan lagi upaya dan kerja sama antara mitra masyarakat untuk meningkatkan kualitas dan produktivitas kompos sehingga dapat tercipta desa yang mandiri pupuk.

\section{SIMPULAN}

Secara umum kegiatan PKW yang telah dilaksanakan di desa Way Tuba Kecamatan Gunung Labuhan dan desa Campur Asri Kecamatan Baradatu Kabupaten Way Kanan telah meningkatkan partisipasi dan pengetahuan masyarakat terhadap paradigma tentang sampah dan pengelolaan sampah dengan konsep 4Rp, pengadaan pupuk/kompos secara mandiri, serta menjadi pelopor pengelolaan sampah berbasis partisipasi aktif dari masyarakat. Selain itu, program ini telah memberikan solusi kepada masyarakat untuk menghasilkan pupuk/kompos secara mandiri, baik digunakan untuk kebutuhan sendiri maupun dijual untuk memenuhi kebutuhan pupuk/kompos di lingkungan sekitarnya.

\section{UCAPAN TERIMA KASIH}

Terima kasih disampaikan kepada Direktorat Riset dan Pengabdian Masyarakat Kemenristekdikti (Surat Penugasan Pelaksanaan Pengabdian kepada Masyarakat No. 452/UN26.21/PM/2018) dan Pemkab Way Kanan yang telah mendanai keberlangsungan kegiatan PKW serta Politeknik Negeri Lampung atas kerja samanya.

\section{DAFTAR PUSTAKA}

Antara Lampung, 2016, http://www.antaralampung.com/berita/289513/kabupaten-waykananakan-bentuk-bank-sampah.Diakses pada tanggal 01 April 2016.

Badan Pusat Statistik Kabupaten Way Kanan, 2014.

Buhani, Suharso, Noviadi, R., 2018, Pengolahan Sampah Rumah Tangga Berbasis Partisipasi Aktif dari Masyarakat Melalui Penerapan Metode 4Rp untuk Menghasilkan Kompos. Jurnal Sakai Sambayan, Vol. $2: 7-13$

Buhani, Narsito, Nuryono, Kunarti, E.S., Suharso, 2015, Adsorption Competition of Cu (II) Ion in Ionic Pair and Multi-Metal Solution by lonic Imprinted Amino-Silica Hybrid Adsorbent. Desalination and Water Treatment, 55(5), 1240-1252.

Buhani, Noviadi, R., Suharso, Alkautsar, R., Anggraini M., Hidayah, T., 2017, Pengolahan Limbah Pertanian Berbasis Partisipasi Aktif dari Masyarakat Melalui Penerapan Metode 4RP untuk 
Website : http://jurnal.untan.ac.id/index.php/JPLP2KM ISSN : $2620-4665$ (print)

ISSN : $2620-4673$ (online)

Meningkatkan Pengadaan Pupuk Secara Mandiri. Seminar Nasional Pengembangan Teknologi Pertanian: Bandar Lampung, Polinela.

Buhani, Suharso, Satria, H., 2011, Hybridization of Nannochloropsis sp Biomass-Silica through Sol-Gel Process to Adsorb Cd (II) Ion in Aqueous Solutions. European Journal of Scientific Research, 51(4), 467-476.

Buhani, Suharso, Aprilia, L., 2012, Chemical Stability and Adsorption Selectivity on $\mathrm{Cd}^{2+}$ Ionic Imprinted Nannochloropsis Sp Material with Silica Matrix from Tetraethyl Orthosilicate. Indonesian Journal of Chemistry, 12(1), 94-99.

Buhani, Musrifatun, Pratama, D.S., Suharso, Rinawati., 2017, Modification of Chaetoceros sp. Biomass with Silica-Magnetite Coating and Adsorption Studies towards $\mathrm{Cu}(\mathrm{II})$ lons in Single and Binary System. Asian Journal of Chemistry ,29 (12), 2734-2739.

Radar Lampung, 2017, Terapkan Metode 4Rp di Way Kanan untuk Mendukung Pengelolaan Sampah Berbasis Partisipasi Warga, I 3 Oktober 2017.

Suharso, Buhani, 2011, Biosorption of Pb (II), Cu (II) and Cd (II) from Aqueous Solution Using Cassava Peel Waste Biomass. Asian Journal of Chemistry, 23(3), 1112-1116.

Tribun Lampung, 2016, Adipati: Way Kanan Siap Aktif Berperan Kurangi Sampah. Minggu, 21 Februari 2016.

Way Kanan Dalam Angka (WKDA), 2015, Blambangan Umpu, Way Kanan 